\title{
Effect of Leaf Loss During Harvest on Subsequent Yield of Coffee
}

\author{
Allan L. Phillips \\ INTRODUCTION
}

The use of mechanical equipment to harvest coffee can result in the removal of some of the leaves during the harvest operation. It seems probable that removal of a large portion of leaves from a tree would result in a reduction in yield during the following year.

Knowledge of the relationship between leaf loss and subsequent yield is useful for evaluating the performance of harvesters which may cause leaf removal. It may also be useful in evaluating the effect on yield of loss of leaves caused by insects and diseases. A preliminary experiment was undertaken to study the effect of leaf loss on subsequent yield.

\section{EXPERIMENTAL PROCEDURE}

Eighteen mature coffee trees of Puerto Rico variety Selección growing at the Limani Substation were selected for this experiment. Six treatments were used with three replicates in each treatment. Leaves were picked by hand from the trees on January 31, 1968, after harvest had been completed. The percent leaf removal was $0,20,40,60,80$, and 100 . During the following crop ripe coffee berries were picked five times, and the yield in grams of berries from each tree weighed and recorded.

In selecting the trees to be used in the experiment, an effort was made to select trees of uniform size and appearance. Uniformity was quite difficult to achieve, however, because of the condition of the trees. As a result, considerable variability thus existed within some of the treatments.

\section{RESULTS AND DISCUSSION}

The total yield for each tree and the mean yield for each treatment are shown in table 1. The yields for each picking and cumulative totals for the complete season are shown in figure 1.

Average yields for each treatment, as shown in figure 1, indicate a decrease in yield due to leaf removal. A linear regression equation was calculated for the effect of leaf removal on yield. The regression equation was:

$$
Y=6453.6-53.58 X
$$

1 Associate Agricultural Engineer, Agricultural Engineering Department, Agricultural Experiment Station, Mayagüez Campus, University of Puerto Rico, Mayagüez, P.R. 
where

$$
\begin{aligned}
& Y=\text { yield, } g \cdot \text { per tree } \\
& X=\text { leaf removal, percent }
\end{aligned}
$$

The regression coefficient of $Y$ on $X$ was found to be $b_{y x}=-53.58$, which is highly significant. The correlation coefficient was found to be: $r=0.7657$.

These results indicate that leaf removal should be taken into considera-

\begin{tabular}{|c|c|c|c|}
\hline Tree number & Leaf removal & Yield & Trestment mean \\
\hline & - Percent & Grams & \\
\hline 24 & 0 & 7473 & \\
\hline 27 & 0 & 7313 & 6440 \\
\hline 31 & 0 & 4516 & \\
\hline 23 & 20 & 2744 & \\
\hline 26 & 20 & 6305 & 5249 \\
\hline 32 & 20 & 6700 & \\
\hline 22 & 40 & 6865 & \\
\hline 25 & 40 & 3132 & 4241 \\
\hline 33 & 40 & 2727 & \\
\hline 21 & 60 & 3311 & \\
\hline 30 & 60 & 1386 & 3120 \\
\hline 34 & 60 & 4563 & \\
\hline 20 & 80 & 4586 & \\
\hline 29 & 80 & 4017 & 3308 \\
\hline 35 & 80 & 1316 & \\
\hline 19 & 100 & 443 & \\
\hline 28 & 100 & 91 & 330 \\
\hline 36 & 100 & 456 & \\
\hline
\end{tabular}
tion in evaluating harvesting systems. No coffee harvesting equipment

currently used or tested has produced excessive leaf losses; nevertheless, the possible disadvantages of moderate or high leaf removal rates should not be overlooked.

None of the trees in the experiment died as a result of leaf removal, and all trees appeared to be normal after several months except for the effects on yield.

Nonuniformity of trees within treatments resulted in quite large variability in the yields. Using a greater number of more nearly uniform trees in an experiment would probably improve reliability of results. 
If leaves are removed from the same tree year after year, there may be a more pronounced effect on yield. It would seem desirable to study leaf loss over several years, and to carry out experiments with a more uniform and better controlled selection of trees.

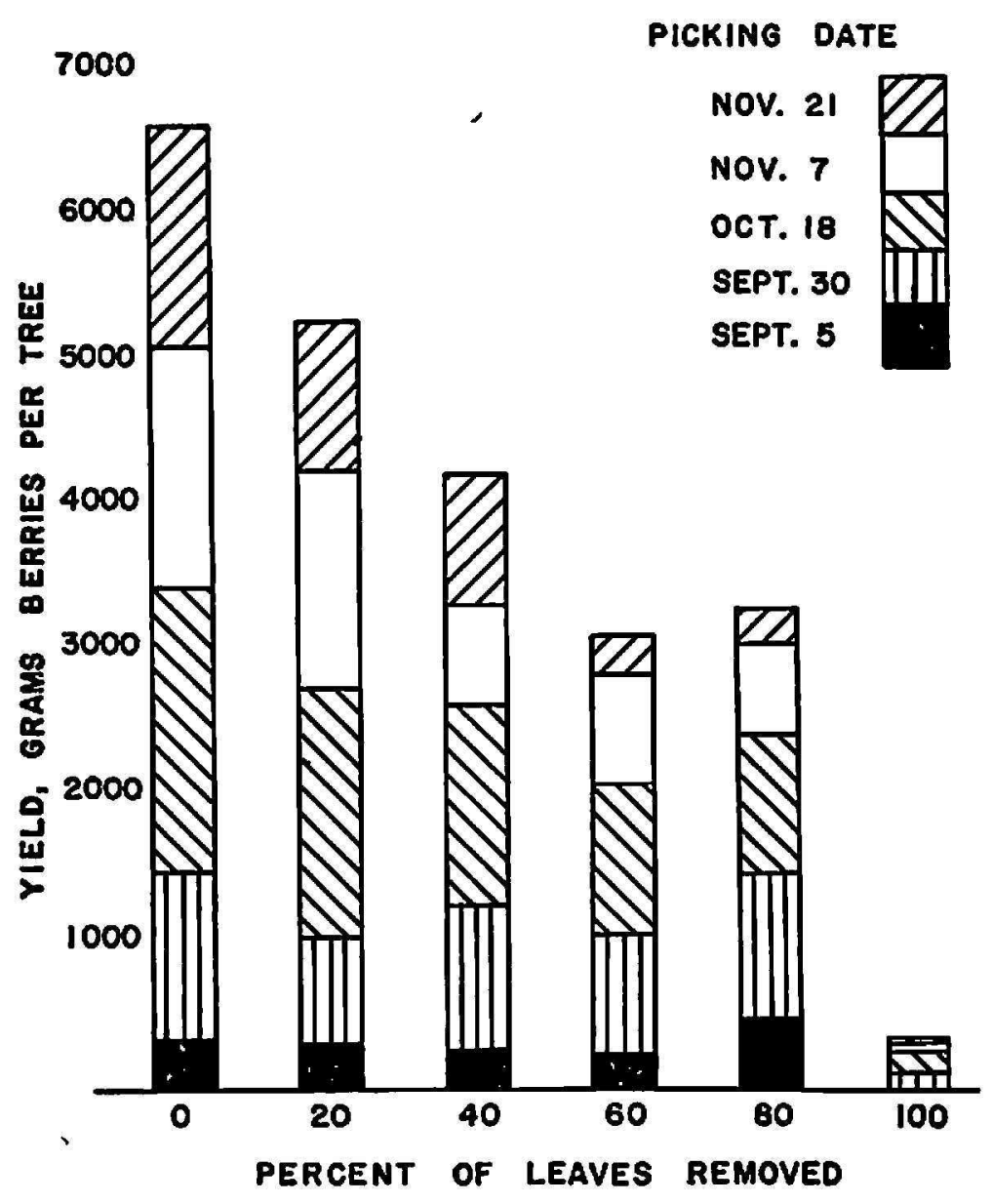

Fig. 1.-Effect of leaf removal on subsequent yield of coffee trees, showing average yields from individual pickings and cumulative total average yields for each treatment.

\section{SUMMARY}

Leaves were removed from coffee trees after harvest at six percentage levels: zero percent (control), 20, 40,60, 80, and 100 percent. A linear regression equation determined from the experimental results showed that yields declined as percent leaf removal increased. The effect of leaf loss should be taken into account in evaluating coffee harvesting systems.

\section{RESUMEN}

Se les eliminaron las hojas a un número de árboles de café después de la cosecha, a seis niveles distintos, a saber: cero por ciento (control), 20, 40, 
60,80 y 100 por ciento. De los resultados obtenidos se determinó una ecuación de regresión linear mostrando que el rendimiento disminuye según aumenta el por ciento de eliminación de las hojas. Al evaluarse un sistema para cosechar café debe tenerse en cuenta el efecto que pueda tener la eliminación de las hojas. 